\title{
Strike slip faulting inferred from offsetting of drainages: Lower Narmada basin, western India
}

\author{
RACHNA RAJ \\ Department of Geology, Faculty of Science, M. S. University of Baroda, Vadodara 390 002, India. \\ e-mail: naveenrachna@gmail.com
}

\begin{abstract}
The detailed analysis of landforms, drainages and geology of the area between the rivers Amaravati and Karjan was carried out in order to understand the tectonic history of the lower Narmada basin. Movement along the various faults in the area was studied on the basis of the drainage offsetting. Horizontal offsetting of stream channels was found quite demonstrable along NNW-SSE trending transverse faults. Tectonic landforms including systematic deflection of stream channels and ridges, alignment of fault scarp and saddles and displacement in the basement rocks and alluvial deposits show that the area is undergoing active deformation driven by the NSF system.
\end{abstract}

\section{Introduction}

The evolution of fault scarps, deformed rivers, marine terraces and the morphology of the mountain fronts have been studied for understanding neotectonic evolution of an area (Morisawa and Hack 1985; Merritts and Hesterberg 1994; Keller and Printer 1996). Tricart (1974) discussed longterm effects of faulting and warping in the offsetting of river courses, formation of lakes and development of meanders. Twidale (1971) suggested that the rise of the fault block across a stream causes either the formation of a lake or swamp or avulsion and development of an irregular or abnormal drainage pattern. Tectonic effect in the drainage pattern of a river becomes obvious if it flows through consolidated rocks (Schumm et al 2000). Recent studies have shown that the detailed examination of drainage patterns can contain much more information on fault evolution (Goldsworthy and Jackson 2000).

It is with this background that the drainage of the area between Amaravati and Karjan Rivers which are the tributaries of the tectonically controlled Narmada River, was studied. The course of the Narmada River is controlled by the NarmadaSon Fault (NSF) which is regarded as a structural discontinuity and is mechanically associated with collision of the Indian and Eurasian plate (Biswas 1987; Vita Finzi 2004). The Narmada-Son Fault (NSF) and other sympathetic faults which crisscross the area have generated earthquakes in the past (Gupta et al 1972; Chandra 1977; Ravishankar 1991). The present study was therefore aimed to understand active tectonics of the above region integrating detailed analysis of landforms, drainages and geological mapping. The study highlights the offsetting in the drainage caused by movements along various NNW-SSE trending transverse faults.

\section{Geology and structure}

River Narmada flows along ENE-WSW trending Narmada-Son Fault (NSF), which constitutes a zone of intense deep-seated faults as revealed by geophysical studies (Reddy et al 1995). This zone is characterised by high gravity anomalies, high temperature gradient and heat flow and anomalous geothermal regime suggesting that the zone is thermomechanically and seismically vulnerable in the framework of contemporary tectonism (Ravishanker 1991; Bhattacharjee et al 1996). The

Keywords. Strike slip faulting; drainage offsetting; active tectonism; lower Narmada basin. 
westward extension of this fault zone into the lower Narmada valley exhibits a less complex structure and is expressed as a single deep-seated fault (NSF). This has also been confirmed by deep seismic sounding studies (Kaila et al 1981). Reactivation of the NSF in the late Cretaceous resulted in the formation of a basin where marine Bagh Beds were deposited (Biswas 1987). NSF remained tectonically active since then with continuous subsidence of the northern block (Biswas 1987). To the south of the NSF, the Tertiary rocks and basaltic flows of Late Cretaceous-Eocene Deccan Traps are exposed (figure 1a). The Tertiary sediments are represented by a full sequence from Eocene to Pliocene overlying the Deccan Trap. The rocks are deformed in the form of several ENEWSW trending anticline and synclines with corresponding topographic highs and lows (figure 1a). Rajpardi Fault separates Tertiary upland from the trappean upland (figure 1a, b). The N-S directed compressive stress during early Quaternary folded the Tertiary sediments into a broad syncline in the rapidly subsiding northern block. The E-W trending axis of this syncline lies to the north of the Narmada River. Corresponding anticlinal structures are found in the Tertiary rocks exposed in the southern upthrown block (Roy 1990) which also comprise the uplands. The lower Narmada basin has yielded geomorphic and stratigraphic information on fault movement within the Narmada-Son Fault which indicate Holocene inversion in response to N-S compression (Chamyal et al 2002).

The study area was taken up to understand the geomorphic and drainage signatures that allow recognition of active faults. It encompasses the area between Amaravati and Karjan Rivers (figure 1a). The eastern part of the study area shows rivers and tributaries following a constricted course characterised by spring, water falls, rapids and gorges (Chamyal et al 2002). The area east of the Rajpardi Fault, which separates trappean rocks from the Cenozoic sediments (figure 1), show intensive ravine development. Several lineaments and faults have been observed in the area trending ENEWSW and NNW-SSE.

\section{Drainage pattern and associated tectonics}

The pattern of the stream development and channel response is a sensitive indicator of active deformation and is key to the understanding of the offsets and evolution of faults in an area (Twidale 2004). The drainage patterns provide a clue to the underlying structure and chronology of the events during drainage evolution (Twidale 2004). In the study area, the rivers flow through two major lithologies, viz., the Deccan Trap and the Tertiary. The area was therefore divided into two distinct domains. Each domain forms a region in which drainages are broadly consistent in characteristics of any predominant direction of flow. As will be seen each domain approximates to a region having a particular geological and tectonic history. In domain 1, which is the northeastern part of the area the drainages generally flow from SSE to NNW or ENE to WSW meeting the Narmada River or its tributaries. Rivers following these trends are Nand Khadi, Chandras Khadi and their tributaries (figure 2). These streams originate south of the NSF and as they cross NSF they show a distinct northwest shift in their courses (figure 2). The river Narmada also shows a northward shift in its course and in digital images a very distinct palaeobank feature (figure 1b) has been marked to the south of the present day channel. The same is very well depicted by a profile section (figure 3). The meandering of the river Narmada can very clearly be seen to be outgrowing towards the NNW direction (figure 1a, b). The drainages in domain 1 are unusual at places. The expected pattern is of parallel stream systems running along the lineaments in traps but they show modifications with lower order streams showing prominent 'palm tree' and fork-shaped aligned in NW-SE to NNWSSE direction. This drainage pattern is indicative of recent activity along faults (Taylor 1991; Twidale 1966; Goldsworthy and Jackson 2000). At certain places the rivers show development of long linear valleys with limited meander development (figures 1b, 2). These have been formed due to the exploitation of fractures by weathering and then by erosion. Short linear sectors (up to few $\mathrm{km}$ but commonly just a few tens of metres) may be related to either joints or faults. Longer straight stretches indicate influence of the faults and some of the straight sectors are aligned parallel with the regional lineament patterns (figures $1 \mathrm{~b}$ and 2 ). The valleys in the southern part of domain 1 are aligned in ENE-WSW direction. The upper reaches of the Madhumati River which flows through this domain in ENE-WSW direction takes a sharp NNW turn at Dholi (figure 4a) following a fault which is transverse to the NSF. The channel of the river shows a very distinct offsetting near Tejpur (figure $4 \mathrm{a}, \mathrm{b}$ ). The valleys towards the north of domain 1 are aligned in NNW-SSE direction. In domain 2, which is the central and western part of the study area the drainges are aligned in NNWSSE direction (figures 2, 4c). In the terrain occupied by Tertiary rocks the courses of the rivers are controlled by the structural highs and lows and faults of the area (figure 1a). The straight stretches in the rivers are also observed in the trappean as well as in the alluvial areas (figures 1b, 2, 4a, b). 


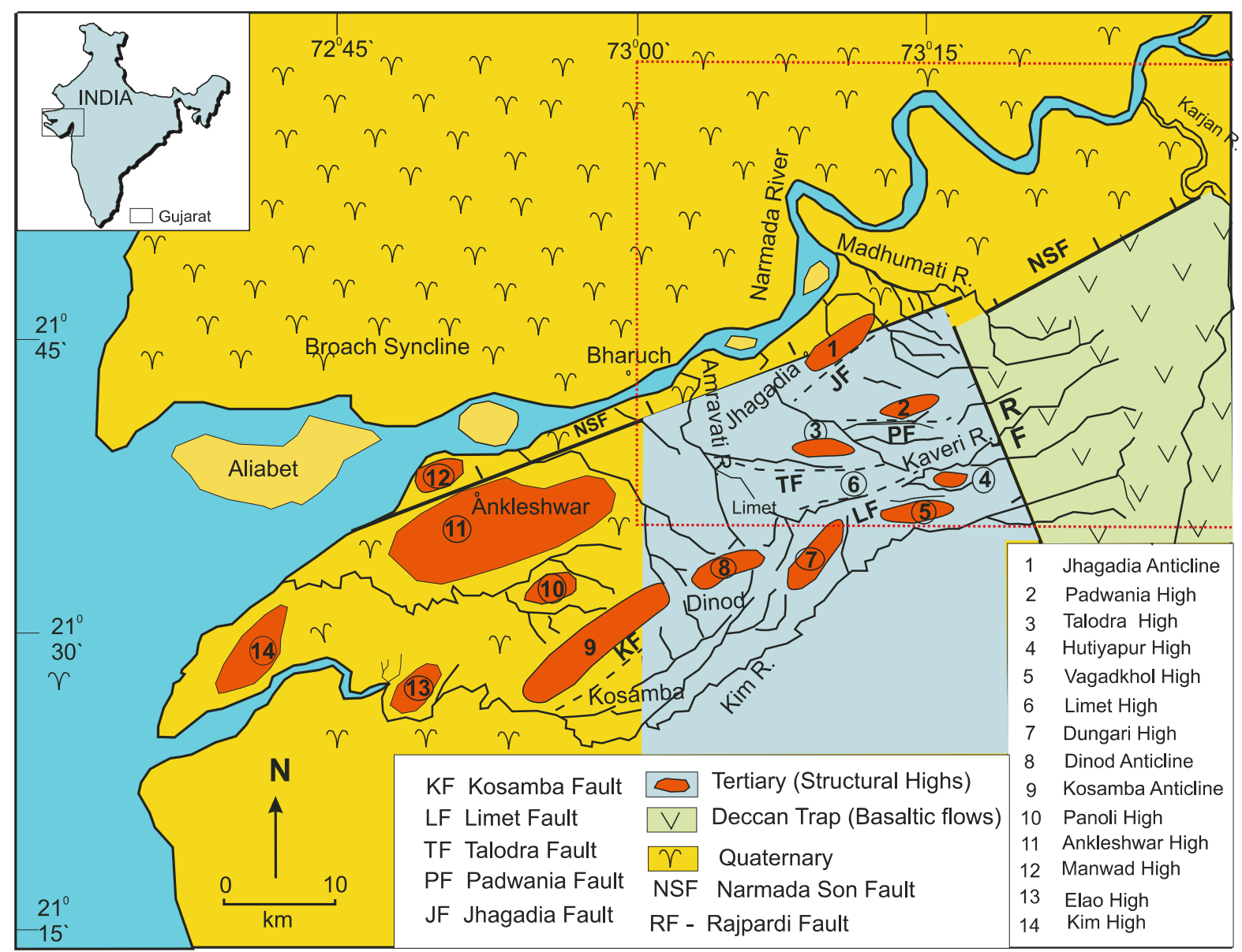

(a)

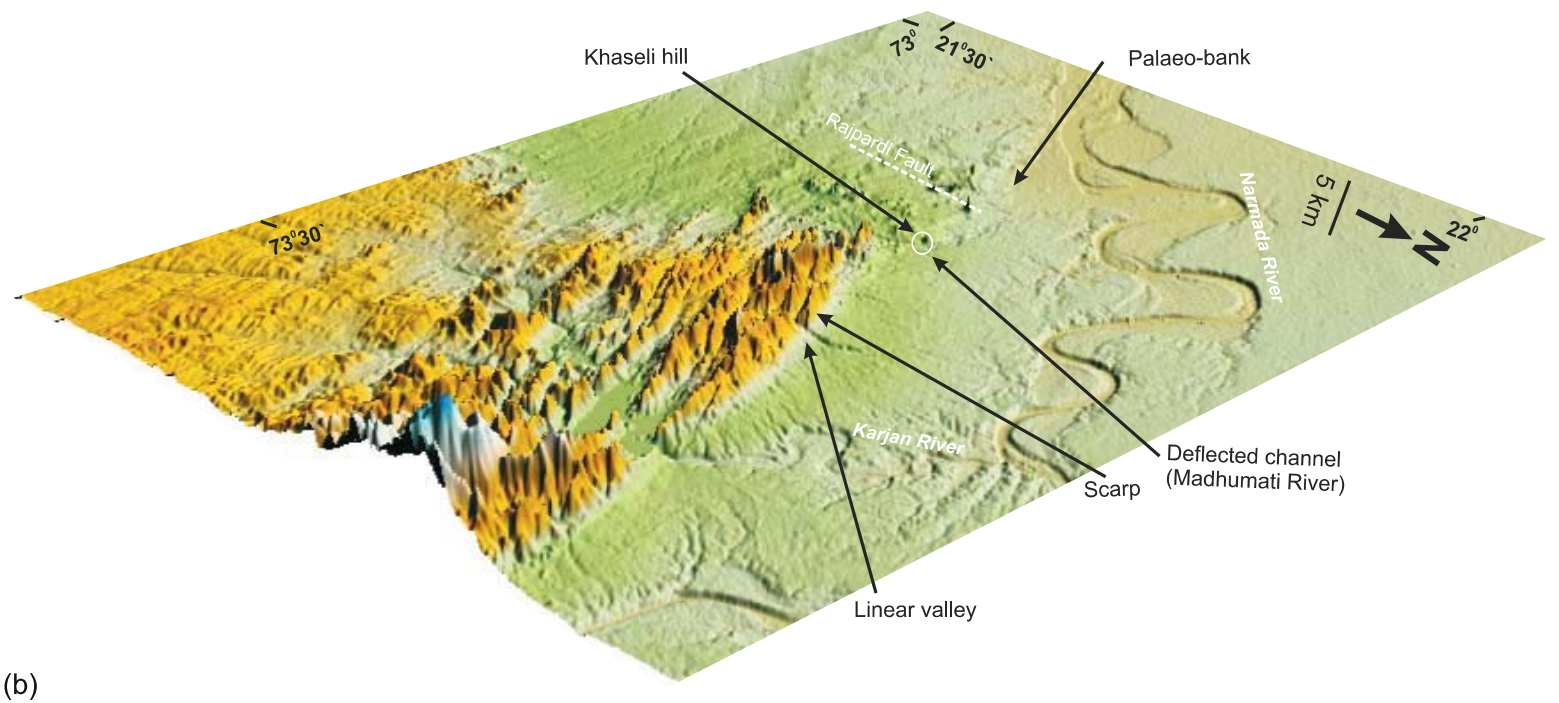

Figure 1. (a) Geological map of a part of lower Narmada valley showing disposition of active faults and structures (Agarwal 1986). Red dotted box represents the area of figure 1(b). (b) Digital Elevation Model (DEM) of the part of Narmada valley showing various tectonic geomorphic features like fault scarp, palaeobank, linear valley and offset channel. Please note that the figure is rotated with $\mathrm{N}$ marked in the lower right corner. DEM was prepared using SRTM data available at CIAT SRTM website (http://srtm.csi.cgiar.org).

The lineaments deduced from the drainage studies correspond to two dominant structural trends, the NNW-SSE and ENE-WSW (figure 2). The
NNW-SSE trending transverse fault between Dholi and Tejpur has displaced the NSF (figure 4a, b). The Rajpardi Fault also follows the same trend. 


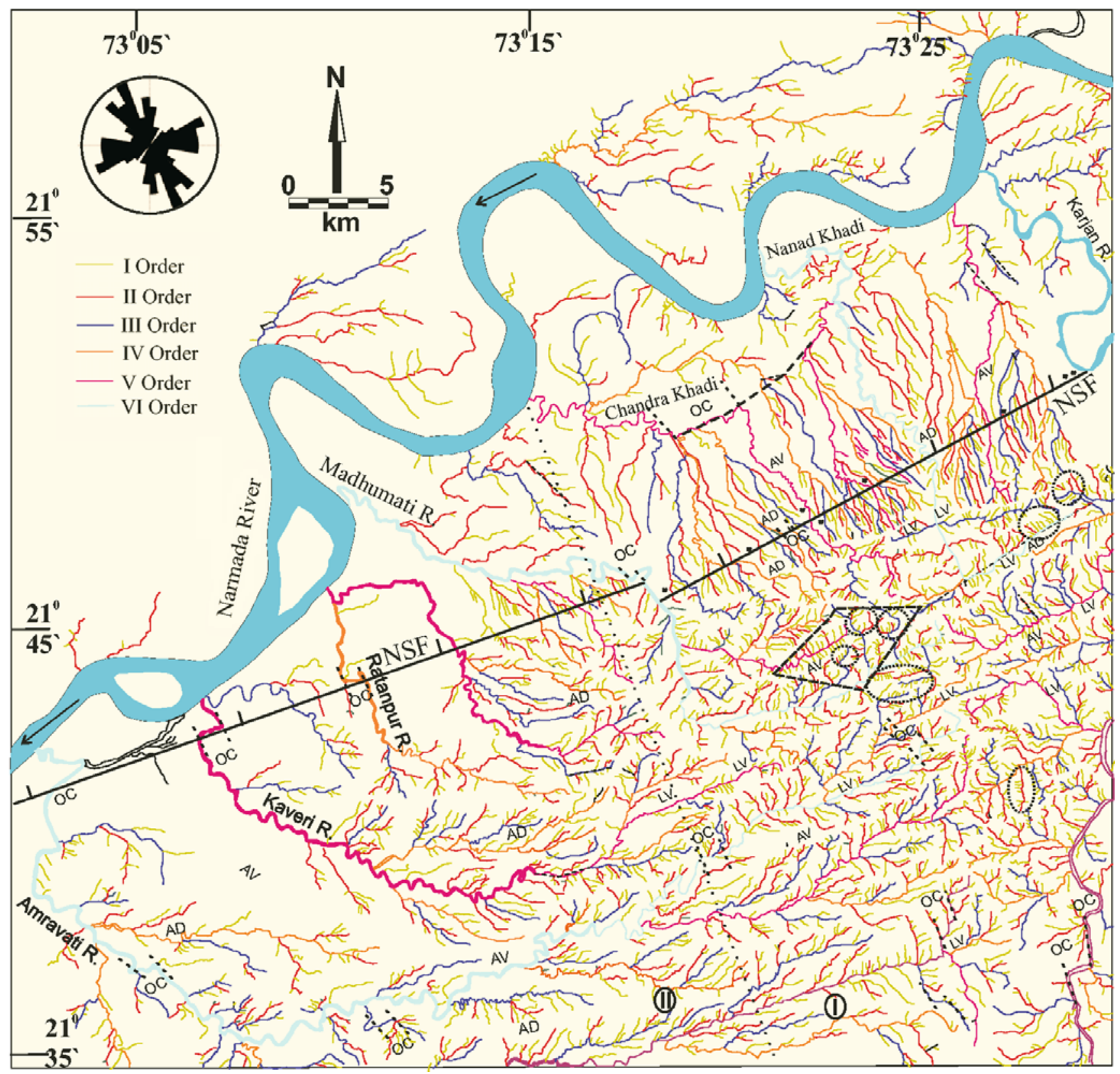

Figure 2. Geomorphic and drainage map of a part of the lower Narmada basin (between Amaravati and Karjan Rivers). Rosette of lineament shows NNW-SSE and ENE-WSW as two dominant trends. I and II indicate domain 1 and domain 2. Geomorphic features like aligned drainage (AD), aligned valley (AV), offset channel (OC), closed depression (CD) and springs $(+)$ are shown. Drainages enclosed in the dotted circles show 'palm-tree' and 'fork' shaped drainages and the area enclosed in dashed rectangle marks the area of figure 6.

The ENE-WSW trend is manifested as linear trappean ridge, intramontane valleys and escarpments in the upland area (figure 1b) and in the drainage courses, particularly of the higher order streams (figure 2). This trend is also dominant in the streams flowing in the alluvial zone. Overall the NNW-SSE and ENE-WSW structural trends have been found to form the regional structural fabric of the area. The same is expressed in various geomorphic features and drainage network of the area.

\section{Offset of stream channels, topographic and geomorphic features}

Offsetting in various landforms is mainly caused by strike slip movement along the faults. Stream channels show disruption or deflection as they meet an active fault. Quantitative evidence of strike slip displacement has been demonstrated from offset ridges, offset alluvial deposits and offset channels. Various geomorphological features identified in the 


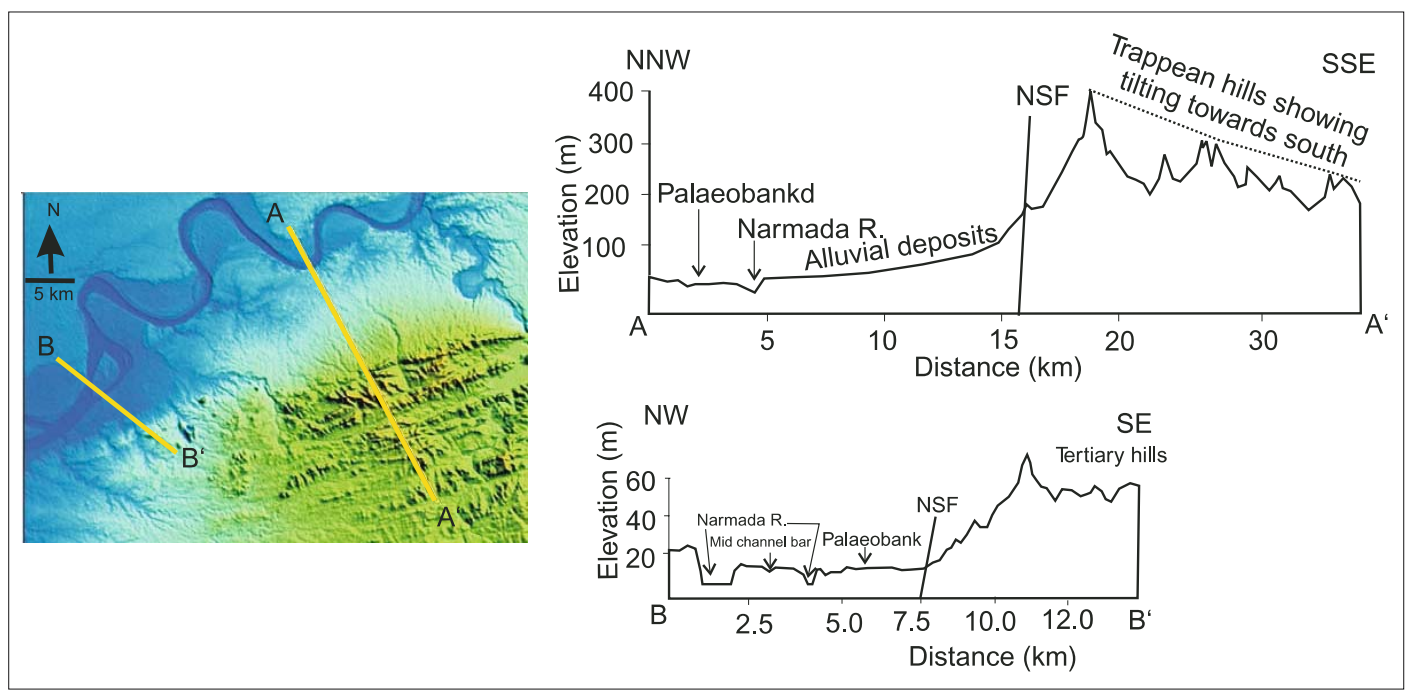

Figure 3. NNW-SSE and NW-SE trending topographic profiles showing position of NSF and other geomorphic features.

area are aligned drainage (AD), aligned valleys $(\mathrm{AV})$, linear valleys $(\mathrm{LV})$, offset channels $(\mathrm{OC})$, and scarps (figure 2). Active strike slips faulting produce these characteristic assemblages of landforms (Keller 1986). The alignment of the drainages and valleys in ENE-WSW and NNW-SSE directions show the influence of lineaments and faults in the area. The activity of faults can be seen in the form of offset channels (OC). Drainages little north of NSF (northeastern part of the figure 2) while flowing in NNW direction show sudden ENEWSW turn marking the influence of a fault trending ENE-WSW. The trappean rocks show tilting (Blanford 1869) which is reflected in the topographic cross section (figure 3 ). The most prominent geomorphological feature associated with NSF is long, incised, sub-parallel streams (figure 2). Faults and lineaments are remarkably straight at places controlling the straight courses of streams in the area. They also mark topographic discontinuity along which intervening valleys and scarps have been developed.

The study shows that there is offsetting at several places in the stream channels (figures 2, 4a, b). The NSF is displaced by a transverse NNW-SSE trending fault. The northern tip of the same lies near Tejpur (figure 4a) which is represented by a $5 \mathrm{~km}$ straight course of river. The offsetting is also observed in the Madhumati channel due to the effect of this fault. The river trends in the NNW-SSE direction in this part. Here a basaltic ridge (Khaseli hill) has also been displaced showing movement in NNW direction (figure 4a). A number of springs have been observed in the vicinity of NSF (figure 2). Two levels of fluvial terraces have developed along the major rivers in the alluvial area, where the older terrace is seen abutting against Khaseli hill (figure 5a). The younger terraces occur at $<6 \mathrm{~m}$ above the stream bed and is comprised of unconsolidated fluvial sands and silts with gravels. In this area, due to the offset and the sudden blocking/beheading of the former courses of the channels, capturing of the channels are evident (figure 2).

The history of a particular fault can be understood properly by accurate knowledge of the amount of fault displacement (Moriyama and Lin 2002). The displacement of the ridge in the area clearly indicates movement along the faults. The basaltic ridge (Khaseli hill) has moved $1.5 \mathrm{~km}$ in the NNW direction along a NNW-SSE trending fault at Tejpur (figures 4, 5a). The river Madhumati also shows offsetting in the same direction following this fault at Tejpur. The streams follow narrow gorge-like valleys that have deeply incised into the hard and compact basaltic rocks. The presence of almost $3-4 \mathrm{~m}$ thick gravel over these trappean rocks (figure 5b) suggests a recent uplift in the area. At several places fault planes were observed with well-developed slickensides. In an attempt to reconstruct the pre-faulting topography by restoring motion on the fault the effect of 210 to $490 \mathrm{~m}$ of displacement along some of the faults is observed (figure 6). While trying to reconstruct the original channel geometry it was possible to calculate a minimum motion along the fault. To reconstruct the original configuration of stream channels, the displacement is reversed to match the stream channels of similar morphology (Moriyama and Lin 2002). An attempt has been made to obtain the quantification of the movement through matching of stream (figure 6). In the figure 6(a) when displacement is reversed by $210 \mathrm{~m}$ the stream channels a-a' to $\mathrm{h}-\mathrm{h}$ ' have 


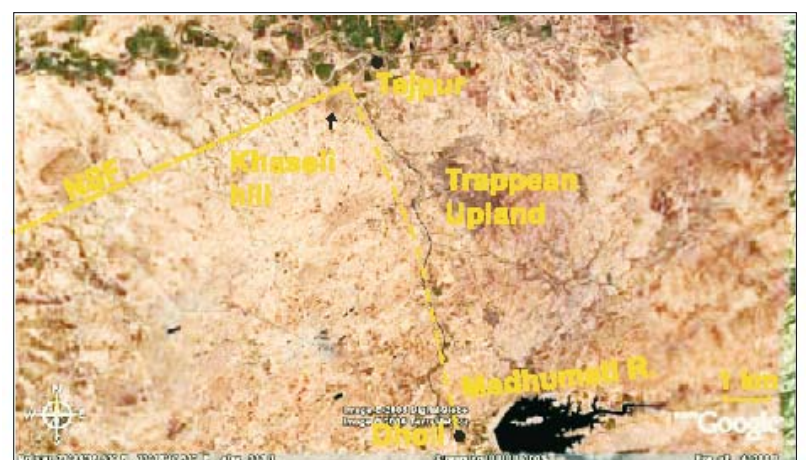

(a)

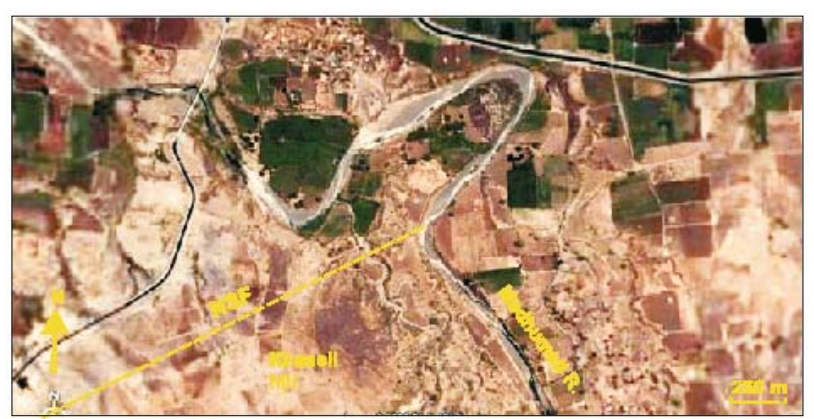

(b)

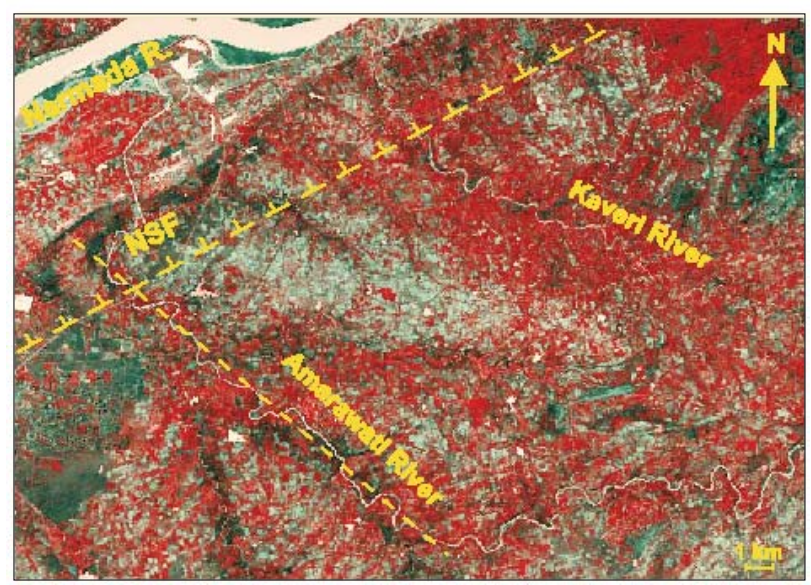

(c)

Figure 4. Distant (a) and close view (b) of the sharp bend of Madhumati River at Dholi and straight course of the river following transverse fault trending NNW-SSE. The river before and after the fault flows in WSW direction. Note the shift in the Khaseli hill by about $1.5 \mathrm{~km}$ in NW direction from the trappean area and offsetting of Madhumati as it crosses the NSF (picture taken from the site: google.com). (c) Map showing trends of drainages in domain 2 (prepared based on SRTM data).

sub-linear courses with comparable channel morphology upstream and downstream of the fault. Accordingly, $210 \mathrm{~m}$ of offset in the stream channel along the strike of the fault has been inferred. Similarly another stream is observed showing offsetting of $\sim 490 \mathrm{~m}$ (figure $6 \mathrm{~b}$ ). Not all the streams are matched by the reconstruction in figure 6(a) and (b). Streams $x$ and $y$ in figure 6(a) have no apparent outlet but this may be because the

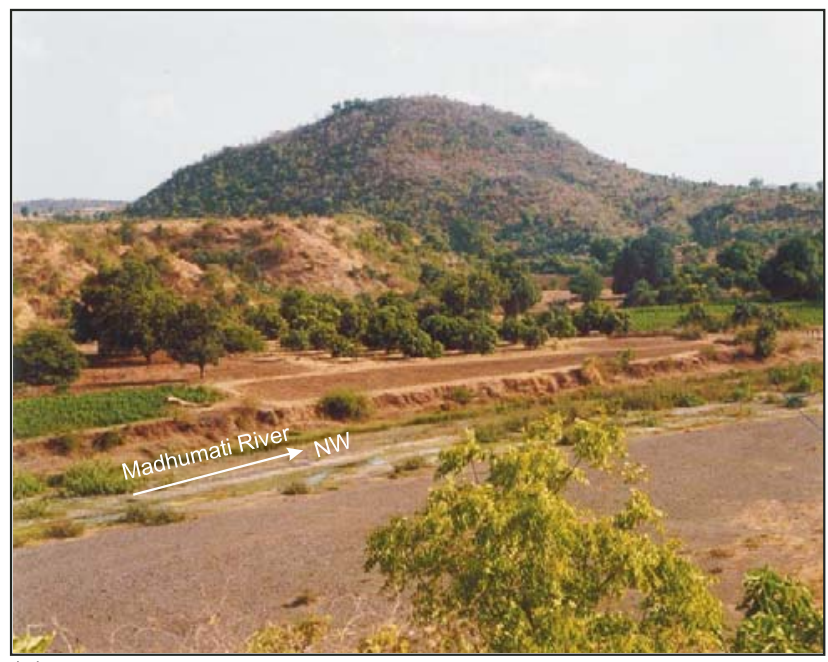

(a)

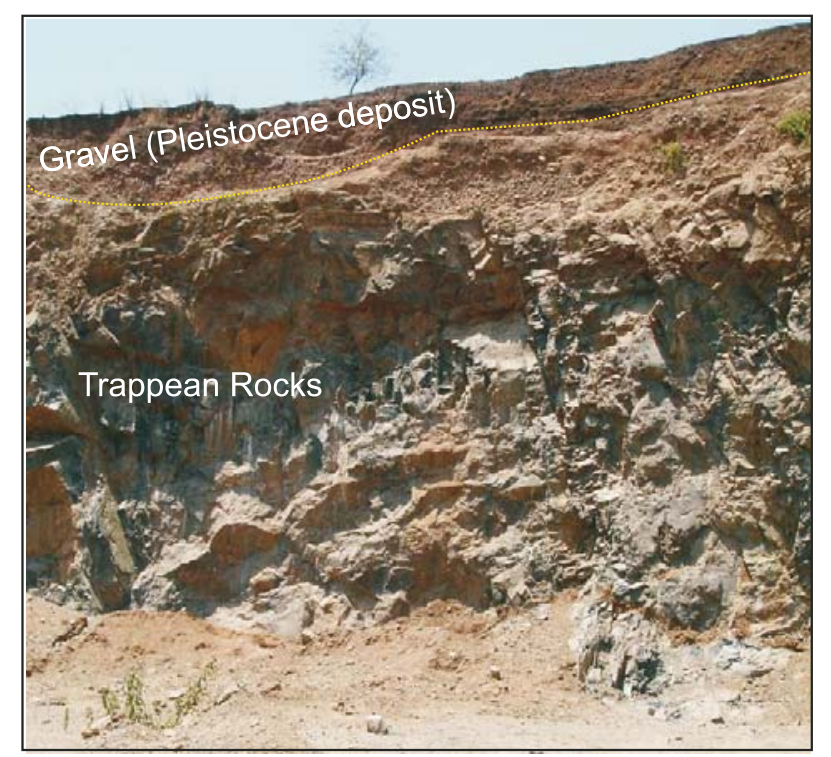

(b)

Figure 5. (a) Two levels of alluvial terraces abutting against the displaced Khaseli hill in the Madhumati River basin. (b) Filed photograph showing incised Pleistocene fluvial gravel over trappean rocks in the upland area.

preservation of their initial courses through the area is too subtle. The reconstruction of offset produces a situation in which one can see much greater continuity in the topography and drainage compared to what is seen today. In the area occupied by domain 2 , the most prominent geomorphic features are Tertiary highs and lows. As the river likes Amaravati, Kaveri, Ratanpur and their tributaries cross NSF (figure 2) they show distinct channel offsetting. Linear valleys are found in this domain following faults and lineaments.

\section{Discussion and conclusion}

A strong link between topography and active deformation is reflected in the geological and 

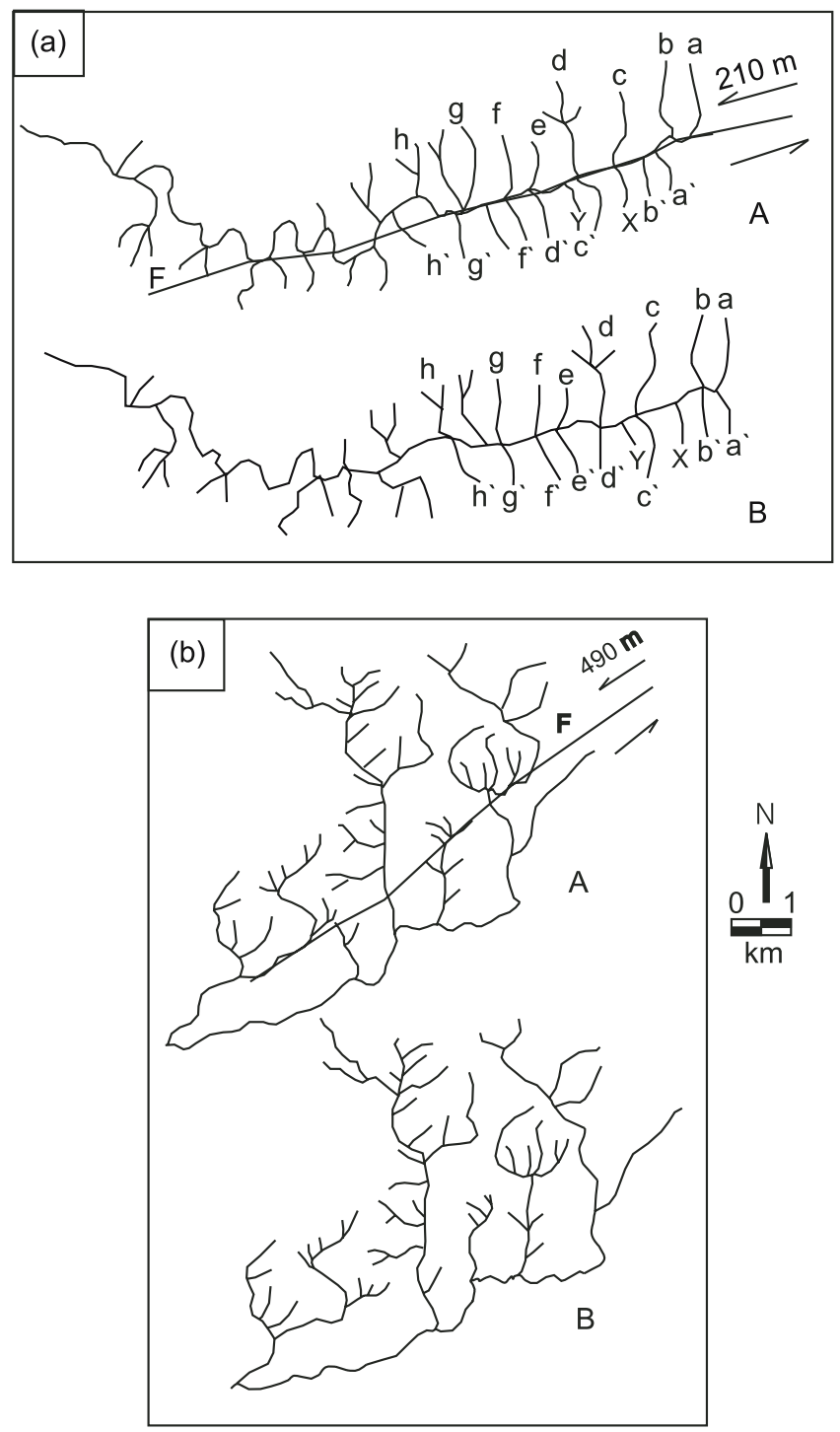

Figure 6. (a) and (b). Restoration of channel offset (A) and their probable position before offsetting (B). Note the location of channels in figure 2 in the vicinity of NSF.

geomorphological set-up of the lower Narmada basin. The rivers show intense incision suggesting recent uplift. The complex drainage pattern of the lower Narmada basin is the result of streams switching or abandoning outlets as they cross the faults along which there is strike slip movement.

The trellis, angular and straight drainage patterns developed in the area point to the influence of structures (Twidale 2004). Higher order streams trend in ENE-WSW direction whereas the lower order streams trend in NNW-SSE direction indicating that as the most recent active trend in the area (Centamore et al 1996). The drainage system in both the domains, comprising varying rocks thus reveal that the NNW-SSE streams have been superimposed on pre-existing ENE-WSW streams. The effect of ENE-WSW system of faults and lineaments are clearly visible in the drainage pattern of the higher order streams to the south of NSF. The response of drainages to the lineaments fracture and faults is seen in the form of sharp angular turns in the courses and at places beheading of streams. Nearly all main streams have smaller parallel to sub-parallel streams feeding them. As the streams cut into the landscape, irregularity in the rate of incision leads to one stream capturing its parallel nearby stream so as to give a "palm tree' and fork-like stream pattern and at places such as 'beheaded' streams (Jackson et al 1998). The faults and lineaments which were active earlier have now been superimposed by the NNWSSE trend. The incision in the streams of the area is indicative of the tectonic activity along these faults. The elevation difference on either side of NSF suggests offset along NSF (Chamyal et al 2002). The drainage in domain 2 is mainly influenced by the subsurface structural highs and lows. In the lower reaches of the Amaravati and Kaveri Rivers, there are several straight sectors which are in conformity with the subsurface structures. The precise mechanism responsible for such underprinting is not clear. Probably the deformation in the basement has induced fractures in the overlying alluvial deposits.

Various workers have characterised and associated tectonic landforms by systematically deflected stream channels, aligned drainages and valley linear valley fault scarps (Okada 1980; Deng et al 1986; Zang et al 1995; Keller 1986). Offset stream channels provide probably, the most convincing evidence for active strike-slip faulting (Wallace 1967; Sieh 1978). In the study area, the horizontal offset of stream channel is quite demonstrable along the various NNW-SSE trending faults. The movement along the NNW-SSE trending transverse faults is manifested in the displacement of ENE-WSW trending NSF. The offsetting in streams and basaltic ridges are of the order of $\sim 490 \mathrm{~m}$ to $1.5 \mathrm{~km}$. Exposures of younger terrace gravels are seen to be cut by the river. The presence of 3-4 m thick fluvial sediments (gravel) over trappean hills indicates active upliftment. Fault scarps are relatively young landforms constituting the most obvious evidence of active faults all over the world (Allen 1975; Allen et al 1984). The Narmada-Son Fault, the other sympathetic faults and various transverse faults display numerous well-preserved scarps throughout their length. The streams of lower Narmada record progressive deformation in the NSF zone. Most of the streams which cross through the faults in the intermontane regions have linear sections above and below the faults, suggesting that they originally cut straight across the fault (Moriyama and Lin 2002). Fluvial terraces at places are displaced vertically (Chamyal et al 2002), showing offset by about 
$35 \mathrm{~m}$ in the area. Tectonic landforms including systematic deflection of stream channels and ridges, alignment of scarps and displacement of alluvial deposits show that the area is undergoing active deformation.

Vita Finzi (2002) has identified ENE-WSW trending Narmada-Son rift as one of the 5 zones of buckling in response to collision of the Indian plate with Eurasian plate. These are the proposed belts of deformation corresponding to the asthenosphere buckling. He has also pointed towards general uplift in the western part of the Narmada Son rift. The northward directed compression has resulted in the development of faults transversely to the shortening direction. The transverse faults inferred in NNW-SSE direction in the study have been releasing the stress generated due to compression. The overprinting of the trends as seen in the drainage pattern is clear evidence of shift in the active tectonic trend in the area towards NNWSSE direction.

\section{Acknowledgements}

The author is thankful to Prof L S Chamyal for his constant encouragement and for critically reading the manuscript. The article is greatly benefited from helpful reviews by two anonymous referees. Department of Science and Technology is thanked for the financial support through research project no. SR/FTP/ES-53/2003.

\section{References}

Allen C R 1975 Geological criteria for evaluating seismicity; Geol. Soc. Am. Bull. 86 1041-1057.

Allen C R, Gillespie A R, Han Y, Sieh K E, Zang B and Zhu C 1984 Red river and associated faults, Yunnan Province, China: Quaternary Geology, slip rates and seismic hazard; Geol. Soc. Am. Bull. 95 686-700.

Agarwal G C 1986 Structure and tectonics of exposed Tertiary rocks between Narmada and Kim rivers in South Gujarat; J. Geol. Soc. India 27 531-542.

Bhattacharjee S, Chatterjee N and Wampler J M 1996 Zones of Narmada-Tapi rift reactivation and Deccan volcanism: geochronological and geochemical evidence; In: Deccan Basalts (eds) Deshmukh S S and Nair K K K, Gondwana Geological Society, Nagpur 329-340.

Blanford W T 1869 On the geology of the Tapti and Lower Narmada valleys and some adjoining districts; Geol. Surv. India Memoir 6 163-384.

Biswas S K 1987 Regional tectonic framework, structure and evolution of western marginal basins of India; Tectonophys. 135 307-327.

Centamore E, Ciccacci S, Del Monte M, Fredi P, Lupia and Pelmieri E 1996 Morphological and morphometric approach to the study of the structural arrangement of the North-Eastern Abruzzo (Central Italy); Geomorphology 16 127-137.

Chamyal L S, Maurya D M, Bhandari S and Rachna Raj 2002 Late Quaternary geomorphic evolution of the lower
Narmada valley, Western India: implications for neotectonic activity along Narmada-Son Fault; Geomorphology 46 177-202.

Chandra U 1977 Earthquakes of peninsular India: a seismotectonic study; Geology 109 263-279.

Deng Q, Chen S, Song F, Zhu S, Wang Y, Zang W, Jiao D, Burchfiel B C, Molnar P, Royden L and Zang P 1986 Variation in the geometry and amount of slip on the Haiyuan (Nanxihaushan) fault zone china and the surface rupture of the 1920 Haiyuan earthquake; In: Earthquake source mechanics; (eds) Das J, Boatwright J, Scholz C H, Geophysical Monograph series $A G U$, Washington DC $\mathbf{3 7}$ 169-182.

Goldsworthy M and Jackson J 2000 Active normal fault evolution in Greece revealed by geomorphology and drainage pattern; J. Geol. Soc. London 157 967-981.

Gupta H K, Mohan I and Narayana B L 1972 The Broach earthquake of March 23, 1970; Bull. Seismol. Soc. Am. $6247-61$.

Jackson J, Dissen V R and Berryman K 1998 Tilting of active folds and faults in the Manawatu region, New Zealand: evidence from surface drainage patterns; New Zealand J. Geol. Geophys. 41 377-385.

Keller E A 1986 Investigation of Active Tectonics: use of surficial Earth Processes; Activer Tectonics: impact on Society 136-147.

Kaila K L, Krishna V G and Mall D 1981 Crustal structure along Mehmadabad-Billimora profile in the Cambay basin, India from deep seismic soundings; Tectonophys. 76 99-130.

Keller C A and Pinter N 1996 Active tectonics: Earthquake, uplift and landscape; Prentice Hall, Upper Saddle River $338 \mathrm{pp}$.

Moriyama T and Lin A 2002 Active strike-slip faulting history inferred from offsets of topographic features and basement rocks: a case study of the Arima-Takasuki tectonic line, southwest Japan; Tectonophys. 344 81-101.

Merritts D and Hesterberg T 1994 Stream networks and long term surface uplift in the New Madrid Seismic Zone; Science 265 1081-1084.

Morisawa M and Hack J T 1985 Tectonic Geomorphology; Allen and Unwin, Boston 390 pp.

Okada A 1980 Fault topography and rate of faulting along the median tectonic line in the drainage basin of the river Yoshino, northeastern Shikoku, Japan; Geographical Review of Japan 43 1-21 (in Japanese with English abstract).

Ravishanker S 1991 Thermal and crustal structure of 'SONATA'. A zone of mid-continental rifting in the Indian shield; J. Geol. Soc. India 37 211-220.

Reddy $\mathrm{P}$ R, Murthy $\mathrm{P}$ R K, Rao I B P, Khare P, Kesava Rao G, Mall D M, Koteshwara Rao P, Raju S, Sridhar V and Reddy M S 1995 Seismic reflection fabric pattern in Central India: preliminary results; J. Geol. Soc. India Memoir 31 537-544.

Roy T K 1990 Structural styles in southern Cambay basin India and role of Narmada geofracture in the formation of giant hydrocarbon accumulation; Bull. Oil and Nat. Gas Comm. 27 15-38.

Schumm S A, Dumont J F and Holbrook J M 2000 Active tectonics and alluvial rivers; Cambridge University Press NY, 276 pp.

Sieh K 1978 Slip along the San Andreas fault associated with the great 1857 earthquake; Bull. Seismol. Soc. Am. 68 1421-1428.

Taylor T G 1991 Physiography of eastern Australia; Commonwealth Bureau of Meteorology Bulletin 8 (18pp).

Tricart J 1974 Structural geomorphology (translated by Beaver S H and Derbyshire E); (Longman: London) $305 \mathrm{pp}$. 
Twidale C R 1966 Geomorphology of the LeichhardtGilbert Area, northwest Queenland; Land Research Series CSIRO Melbourne $\mathbf{1 6} 56 \mathrm{pp}$.

Twidale C R 1971 Structural landforms; Australian National Univ. Press, Canberra.

Twidale C R 2004 River patterns and their meaning; Earth Sci. Rev. 67 159-218.

Vita Finzi C 2002 Interplate neotectonics in India; Curr. Sci. 82 400-402.
Vita Finzi C 2004 Buckle controlled seismogenic faulting in peninsular India; Quat. Sci. Rev. 23 2405-2412.

Wallace R E 1967 Note on stream channels offset by the San Andreas fault, Southern coast Ranges, California; Stanford University Publ., Geol. Sci. 11 6-20.

Zang Y Q, Vergely P and Mercier J 1995 Active faulting in and along the Quinling Range (China) inferred from SPOT imagery analysis and extension tectonics of south China; Tectonophys. 243 69-95.

MS received 22 September 2006; revised 16 February 2007; accepted 13 April 2007 